\title{
Floral Development and Flower Longevity in Rhipsalidopsis and Schlumbergera (Cactaceae)
}

\author{
Deirdre Scott ${ }^{1}$, Thomas H. Boyle ${ }^{2}$, and Susan S. Han ${ }^{3}$ \\ Department of Plant and Soil Sciences, University of Massachusetts, Amherst, \\ MA 01003
}

\begin{abstract}
Additional index words. abscission, Easter cactus, flowering, Holiday cactus, ornamental plants, postharvest physiology, senescence
\end{abstract}

\begin{abstract}
Eight Easter cactus (Rhipsalidopsis Britt. \& Rose) cultivars and five Holiday cactus (Schlumbergera Lem.) cultivars were used to study postanthesis floral development and individual flower longevity. Floral aging was characterized by desiccation of the perianth and ovary, and was generally followed by abscission of the entire flower from the phylloclade. Petal turgor was maximal during early development when petal color was most intense. Petal color became less intense in the later stages of development. Flower longevity ranged from 7 to 12 days and from 4 to 6 days for the Rhipsalidopsis and Schlumbergera, respectively. This study demonstrates that significant genetic variation occurs within Rhipsalidopsis and Schlumbergera for flower longevity.
\end{abstract}

Easter cactus [Rhipsalidopsis spp. and interspecific hybrids (Liberty Hyde Bailey Hortorium, 1976)] and Holiday cactus [Schlumbergera spp. and interspecific hybrids (Hunt, 1981; Liberty Hyde Bailey Hortorium, 1976; Poole et al., 1981)] are popular, flowering, potted plants in North America and northern Europe. There have been few postproduction studies of these two crops. Poole (1973) reported that S. truncata(Haw.) Moran 'Christmas Cheer' plants continued flowering for 4 to 6 weeks after anthesis of the first flower. According to Patch (1977), the longevity of individual flowers is 6 to 9 days for $S$. truncata. However, the environmental conditions maintained during evaluation of flowering were not specified in either Poole's (1973) or Patch's (1977) work. In addition, the criteria for evaluating flower longevity have not been defined for Schlumbergera (Patch, 1977; Poole, 1973) or Rhipsalidopsis.

Identification of Rhipsalidopsis and Schlumbergera cultivars with superior flower longevity would be useful for commercial growers and breeders. Information on morphological changes during floral development would aid in defining flower longevity. The objectives of this investigation were to 1) study the morphology of Rhipsalidopsis and Schlumbergera flowers from anthesis through senescence and 2) determine flower longevity for several Rhipsalidopsis and Schlumbergera cultivars.

\footnotetext{
Received for publication 23 Aug. 1993. Accepted for publication 21 Jan. 1994. Publication no. 3092 of the Massachusetts Agricultural Expt. Station. The cost of publishing this paper was defrayed in part by the payment of page charges. Under postal regulations, this paper therefore must be hereby marked advertisement solely to indicate this fact.

${ }^{1}$ Graduate Student.

${ }^{2}$ Associate Professor; to whom reprint requests should be addressed.

${ }^{3}$ Assistant Professor.
}

\section{Materials and Methods}

Plant material and cultural procedures. Eight Rhipsalidopsis and five Schlumbergera cultivars were propagated and grown in glasshouses at the Univ. of Massachusetts (UMass), Amherst (lat. $42^{\circ} 22.5^{\prime} \mathrm{N}$ ). Cultivars were chosen randomly from the collection of Rhipsalidopsis and Schlumbergera clonal germplasm maintained at UMass. Two of the Schlumbergera cultivars (88-50 and 88-68) were developed at UMass and were late-flowering selections from an $\mathrm{F}_{1}$ population of $S$. truncata 'Rocket' x S. ×buckleyi (T. Moore) Tjaden 'Buckleyi' (Hunt, 1981); all other cultivars used in this study were commercial clones of unknown parentage.

Phylloclades were propagated in mid-Feb. 1991, using one or two phylloclades per 35$\mathrm{cm}^{3}$ cell. Plants were transplanted into 220 $\mathrm{cm}^{3}$ plastic pots $(7.6 \mathrm{~cm}$ in diameter) in midJune. A commercial soilless mix (Fafard Mix no. 2; Conrad Fafard, Springfield, Mass.) was used as the propagation and growing medium. Plants were fertilized weekly with $20 \mathrm{~N}-4.3 \mathrm{P}-$ $16.6 \mathrm{~K}\left(12 \% \mathrm{NO}_{3}-\mathrm{N}, 8 \% \mathrm{NH}_{4}-\mathrm{N}\right)$ at $200 \mathrm{mg} \mathrm{N} /$ liter. Fertilization began after phylloclades were rooted and continued until the start of growth chamber experiments. Photoperiod and temperature were regulated to manipulate flowering (Boyle, 1990, 1991; Boyle and Jacques, 1990). Immature apical phylloclades were removed 1 week after the start of inductive treatments to promote uniform bud development.

Stages of floral development. Plants with several mature flower buds $(\approx 1$ or 2 days before anthesis) were transferred from the glasshouse to a controlled-environment chamber (model 1-35LVL; Percival Manufacturing Co., Boone, Iowa). Chamber conditions were $20 \pm 1 \mathrm{C}, 75 \% \pm 5 \%$ relative humidity $(\mathrm{RH})$, and a 12-h photoperiod (0600 to $1800 \mathrm{HR}$ ) provided by cool-white fluorescent lamps [52 $\pm 8 \mu \mathrm{mol} \cdot \mathrm{s}^{-1} \cdot \mathrm{m}^{-2}$ photosynthetic photon flux
(PPF)]. A thermistor (LI-1000-16; LI-COR, Lincoln, Neb.) and a quantum sensor (LI190SA; LI-COR) recorded air temperatures and PPF, respectively. A hygrometer (model 22-7059; Bacharach Instrument Co., Pittsburgh) measured RH. Plants were irrigated with tap water $\left(\leq 0.12 \mathrm{dS} \cdot \mathrm{m}^{-1}\right.$ electrical conductivity) when the media surface was dry.

Perianth turgor was evaluated subjectively as fully turgid (no wilting), slightly flaccid (onset of visible wilting), or moderately to severely flaccid. Petal color was characterized qualitatively with the Royal Horticultural Society (RHS) Colour Chart (RHS, 1966). Fully expanded petals were compared with the RHS Coulour Chart to determine the color chip(s) closest to the predominant petal color. Kelly and Judd's (1976) color names dictionary was used for naming petal colors. Petal orientation was defined as the angle between a line parallel to the floral tube and a line from the base to the tip of the perianth segment $\left(0^{\circ}\right.$ petal orientation-perianth parallel to the floral tube). One petal orientation measurement was obtained per flower. Petal orientation of zygomorphic Schlumbergera flowers was measured on the uppermost apical perianth segment at the distal end of the floral tube. Perianth segments within individual Rhipsalidopsis flowers did not differ in petal orientation due to the actinomorphic floral symmetry; therefore, petal orientation was measured on random perianth segments within each flower. Stigmatic lobe orientation was defined as the angle between a line parallel to the style and a line from the base to the tips of the stigmatic lobes. For each cultivar, data were collected on 10 flowers on four or more individual plants. Pots were randomized within the chamber and spaced $\approx 12 \mathrm{~cm}$ apart. Rhipsalidopsis flowers exhibited nyctinasty (diurnal opening), and all data were collected during the middle of the photoperiod regime (1100 to $1300 \mathrm{HR}$ ), when petal orientation for Rhipsalidopsis flowers was maximum.

\section{Results and Discussion}

Developmental stages. Four developmental stages from anthesis to senescence were defined for Rhipsalidopsis and Schlumbergera flowers: early, middle, late, and senescent (Table 1). For Rhipsalidopsis cultivars, perianth turgor was maximal during the early and middle stages. It began to decline during the late stage and was minimal in the senescent stage (Table 1). Petal orientation increased from $\approx 10^{\circ}$ at anthesis to a maximum of $\approx 90^{\circ}$ in the middle stage and then decreased to $0^{\circ}$ at senescence (Fig. 1). Rhipsalidopsis petal color was most intense in the early stage and faded progressively during the middle and late stages (Table 2). Stigmatic lobe orientation increased from $\approx 0^{\circ}$ to $30^{\circ}$ at anthesis to a maximum of $\approx 90^{\circ}$ in the middle, late, and senescent stages (Table 1, Fig. 1). Morphological changes occurred in the stigmatic lobes during flower development: lobes were erect during the early and middle stages but became reflexed during the late and senescent stages (Fig. 1). Stigmatic lobes of Echinocereus fasciculatus 
(Englem.) L. var. boyce-thompsonii (Orcutt) L. Benson exhibited similar morphological changes during floral development (Grant and Grant, 1979).

Perianth turgor was maximal in Schlumbergera cultivars during the early and middle stages, and it declined progressively from the late to the senescent stage (Table 1). Petal orientation increased from $\approx 10^{\circ}$ at anthesis to $>45^{\circ}$ in the middle and late stages,

Table 1. Stages of Rhipsalidopsis and Schlumbergera flower development.

\begin{tabular}{|c|c|c|}
\hline Stage & $\begin{array}{l}\text { Duration } \\
(\text { days })^{z}\end{array}$ & Description $^{\mathrm{y}}$ \\
\hline & & Rhipsalidopsis \\
\hline Early & $1.9 \pm 0.1$ & $\begin{array}{l}\text { Perianth fully turgid; petal orientation } \approx 10^{\circ} \text {; maximal intensity of } \\
\text { petal color; stigmatic lobe orientation } 0^{\circ} \text { to } 30^{\circ} \text {; stigmatic lobes } \\
\text { erect. }\end{array}$ \\
\hline Middle & $5.6 \pm 0.3$ & $\begin{array}{l}\text { Perianth fully turgid; petal orientation } \approx 20^{\circ} \text { to } 90^{\circ} \text {; petal color } \\
\text { begins to fade; stigmatic lobe orientation } \approx 20^{\circ} \text { to } 90^{\circ} \text {; stigmatic } \\
\text { lobes erect. }\end{array}$ \\
\hline Late & $2.1 \pm 0.5$ & $\begin{array}{l}\text { Perianth slightly flaccid; petal orientation } \approx 30^{\circ} \text { to } 60^{\circ} \text {; progressive } \\
\text { petal fading; stigmatic lobe orientation } \approx 45^{\circ} \text { to } 90^{\circ} \text {; stigmatic } \\
\text { lobes slightly reflexed. }\end{array}$ \\
\hline Senescent & $1.6 \pm 0.3$ & $\begin{array}{l}\text { Perianth moderately to severely flaccid; petal orientation } 0^{\circ} \text {; petal } \\
\text { color at minimal intensity; stigmatic lobe orientation } \approx 90^{\circ} \text {; } \\
\text { stigmatic lobes moderately reflexed. }\end{array}$ \\
\hline & & Schlumbergera \\
\hline Early & $1.0 \pm 0.0$ & $\begin{array}{l}\text { Perianth fully turgid; petal orientation } \approx 10^{\circ} \text {; maximal intensity of } \\
\text { petal color; stigmatic lobes appressed. }\end{array}$ \\
\hline Middle & $2.4 \pm 0.2$ & $\begin{array}{l}\text { Perianth fully turgid; petal orientation } \approx 45^{\circ} \text { to } \geq 90^{\circ} \text {; petal color } \\
\text { begins to fade; stigmatic lobe orientation } \leq 15^{\circ} \text {. }\end{array}$ \\
\hline Late & $1.8 \pm 0.4$ & $\begin{array}{l}\text { Perianth slightly flaccid; petal orientation } \approx 45^{\circ} \text { to } 90^{\circ} \text {; progressive } \\
\text { petal fading; stigmatic lobe orientation } \leq 15^{\circ} \text {. }\end{array}$ \\
\hline Senescent & $1.0 \pm 0.0$ & $\begin{array}{l}\text { Perianth moderately to severely flaccid; petal orientation } \approx 0^{\circ} \text {; } \\
\text { petal color at minimal intensity; stigmatic lobe orientation } \leq 15^{\circ} \text {. }\end{array}$ \\
\hline
\end{tabular}

${ }^{z}$ Mean of eight Rhipsalidopsis cultivars \pm SE, or five Schlumbergera cultivars \pm SE.

${ }^{y}$ Descriptions indicate the beginning of each stage.
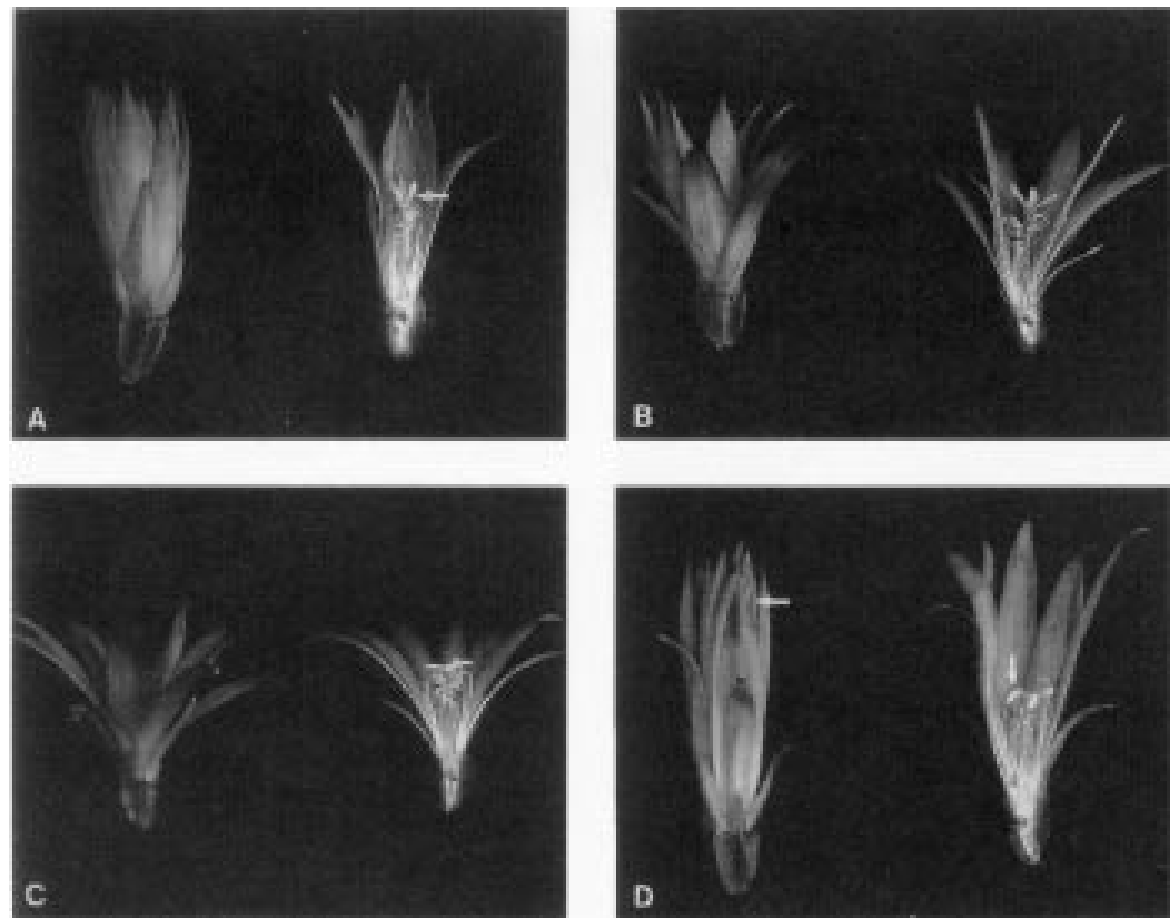

Fig. 1. Floral development stages in Rhipsalidopsis 'Crimson Giant' from anthesis to senescence. (A) Early stage, with flowers showing erect stylar lobes (arrow). (B) Middle stage. (C) Late stage. (D) Senescent stage, with flowers showing flaccid petal tips (left arrow) and reflexed stylar lobes (right arrow). (left) Intact flowers and (right) longitudinal sections are shown in each photograph.
Flower longevity. For Rhipsalidopsis and Schlumbergera, flower longevity was defined as the number of days from the onset of the early stage (anthesis) until the start of the senescent stage. Flower longevity data demonstrated variance heterogeneity and were transformed $\left[\log _{10}(\mathrm{x}+1)\right]$ before analysis of variance (SAS Institute, 1985). Flower longevity ranged from 6.7 to 12.2 days for the Rhipsalidopsis cultivars and from 4.3 to 6.2 days for Schlumbergera (Table 2).

The normal pattern of floral aging, exhibited by all of the Rhipsalidopsis and Schlumbergera cultivars, except for 'Mira', was senescence and desiccation of the perianth and ovary, followed by abscission of the entire flower from the phylloclade. A similar pattern of floral aging was reported for Opuntia compressa (Salis.) McBride [O. humifusa (Raf.) Raf.] (Grant and Connell, 1979) and appears to be characteristic of many Cactaceae species (Went, 1982). For 'Mira', however, flowers senesced but did not abscise, and ovaries eventually differentiated into fruit that contained many viable seeds (data not presented). 'Mira' flowers likely were not crosspollinated in the growth chamber due to spatial separation between cultivars $(\approx 12 \mathrm{~cm}$ minimum distance) and pollen vector exclusion (insects). Furthermore, isolated Rhipsalidopsis and Schlumbergera plants normally fail to set fruit due to the presence of selfincompatibility (Ganders, 1976; Taylor, 1976). Thus, our results suggest that 'Mira' is selfcompatible or apomictic. It should be noted that flower longevity for 'Mira' was significantly less than for other Rhipsalidopsis cultivars (Table 2). The nature of the relationship between seed set and floral longevity in Rhipsalidopsis needs to be determined.

For potted plants with numerous flowers, flower longevity partially defines the duration that plants remain attractive; therefore, it is a major component of plant quality. Cultivars with superior flower longevity are expected to lead to greater consumer satisfaction and repeat purchasing (Langton, 1991). Our results indicate that, within both genera, there were significant differences in flower longevity between cultivars (Table 2). Thus, selection of Rhipsalidopsis and Schlumbergera cultivars with increased flower longevity is feasible. Genotypic differences in flower longevity have been reported in several other floricultural crops, including Dianthus caryophyllus (Wu et al., 1991), Gerbera hybrida (De Jong and Garretsen, 1985; Harding et al., 1981), Pelargonium $\times$ domesticum (Deneke et al., 1990; Evensen and Olson, 1992), and Tulipa (Van Eijk and Eikelboom, 1976). The physiological or genetic basis for diversity within Rhipsalidopsis and Schlumbergera for flower longevity needs to be determined

\section{Literature Cited}

Boyle, T.H. 1990. Using temperature to control flowering of Holiday cactus. Floral Notes 3(1):6-8.

Boyle, T.H. 1991. Temperature and photoperiodic regulation of flowering in 'Crimson Giant' Easter cactus. J. Amer. Soc. Hort. Sci. 116:618622. 
Table 2. Petal color and flower longevity for Rhipsalidopsis and Schlumbergera cultivars.

\begin{tabular}{|c|c|c|c|c|c|c|}
\hline \multirow[b]{2}{*}{ Cultivar } & \multirow{2}{*}{$\begin{array}{c}\text { Predominant } \\
\text { petal color }^{\mathrm{y}}\end{array}$} & \multicolumn{4}{|c|}{$\begin{array}{c}\text { Floral development } \\
\text { stage }^{z}\end{array}$} & \multirow{2}{*}{$\begin{array}{r}\text { Flower } \\
\text { longevity } \\
(\text { days })^{\mathrm{x}} \\
\end{array}$} \\
\hline & & $\mathrm{E}$ & M & $\mathrm{L}$ & $\mathrm{S}$ & \\
\hline \multicolumn{7}{|c|}{ Rhipsalidopsis } \\
\hline Andre & Vivid red & $44 \mathrm{~A}^{\mathrm{w}}$ & $44 \mathrm{~A}$ & 44B & 44B & $9.6 b^{v}$ \\
\hline Crimson Giant & Strong red & $34 \mathrm{~A}$ & $34 \mathrm{~B}$ & $34 \mathrm{BC}$ & $34 \mathrm{C}$ & $10.8 \mathrm{ab}$ \\
\hline Evita & Deep purplish pink & $74 \mathrm{~A}$ & 74B & $74 \mathrm{BC}$ & $74 \mathrm{C}$ & $11.1 \mathrm{ab}$ \\
\hline Thor-Anne & Vivid red & $45 \mathrm{~A}$ & $45 \mathrm{~A}$ & $45 \mathrm{CD}$ & $45 \mathrm{CD}$ & $11.3 \mathrm{a}$ \\
\hline Mira & Deep purplish pink & $74 \mathrm{~A}$ & $74 \mathrm{~B}$ & 74BC & $74 \mathrm{C}$ & $6.7 \mathrm{c}$ \\
\hline Purple Pride & Deep purplish pink & $74 \mathrm{~B}$ & $74 \mathrm{~B}$ & $74 \mathrm{BC}$ & $74 \mathrm{C}$ & $10.6 \mathrm{ab}$ \\
\hline Red Pride & Strong red & $34 \mathrm{~A}$ & $34 \mathrm{~B}$ & 34B & $34 \mathrm{BC}$ & $12.2 \mathrm{a}$ \\
\hline Rood & Vivid red & $44 \mathrm{~A}$ & $44 \mathrm{~B}$ & $44 \mathrm{BC}$ & $44 \mathrm{BC}$ & $12.1 \mathrm{a}$ \\
\hline \multicolumn{7}{|c|}{ Schlumbergera } \\
\hline Christmas Fantasy & Moderate reddish orange & $37 \mathrm{~A}$ & $37 \mathrm{~B}$ & $37 \mathrm{~B}$ & $37 \mathrm{C}$ & $6.2 \mathrm{a}$ \\
\hline Dark Marie & Vivid red & $46 \mathrm{~B}$ & $46 \mathrm{~B}$ & $46 \mathrm{C}$ & $46 \mathrm{CD}$ & $4.3 \mathrm{~b}$ \\
\hline Linda & Vivid red & $53 \mathrm{C}$ & $53 \mathrm{C}$ & $53 \mathrm{CD}$ & $53 \mathrm{CD}$ & $4.6 \mathrm{~b}$ \\
\hline $88-50$ & Deep purplish pink & $74 \mathrm{~A}$ & 74B & $74 \mathrm{BC}$ & $74 \mathrm{C}$ & $5.1 \mathrm{ab}$ \\
\hline $88-68$ & Deep purplish red & $74 \mathrm{~B}$ & $74 \mathrm{~B}$ & $74 \mathrm{AB}$ & $74 \mathrm{~A}$ & $5.7 \mathrm{a}$ \\
\hline
\end{tabular}

${ }^{\mathrm{z}} \mathrm{E}=$ early, $\mathrm{M}=$ middle, $\mathrm{L}=$ late, and $\mathrm{S}=$ senescent.

${ }^{y}$ Color names from Kelly and Judd (1976) color standards.

xDays from anthesis to commencement of senescence (mean of 10 observations).

${ }^{\text {w }}$ Royal Horticultural Society (RHS) Colour Chart numbers that are closest to the predominant petal color at each developmental stage. The RHS Colour Chart is composed of 202 sheets containing four chips per sheet ( 808 color chips total). Each sheet is designated by a number, and each of the four color chips on a sheet is specified by a letter (A, B, C, or D). For each sheet, the color is progressively lightened from the A to the D chip. Color chart numbers with two letters describe petal colors that are intermediate between two adjacent color chips.

${ }^{\vee}$ Mean separation of cultivars within Rhipsalidopsis or Schlumbergera by Tukey's Studentized range test, $P \leq 0.05$.
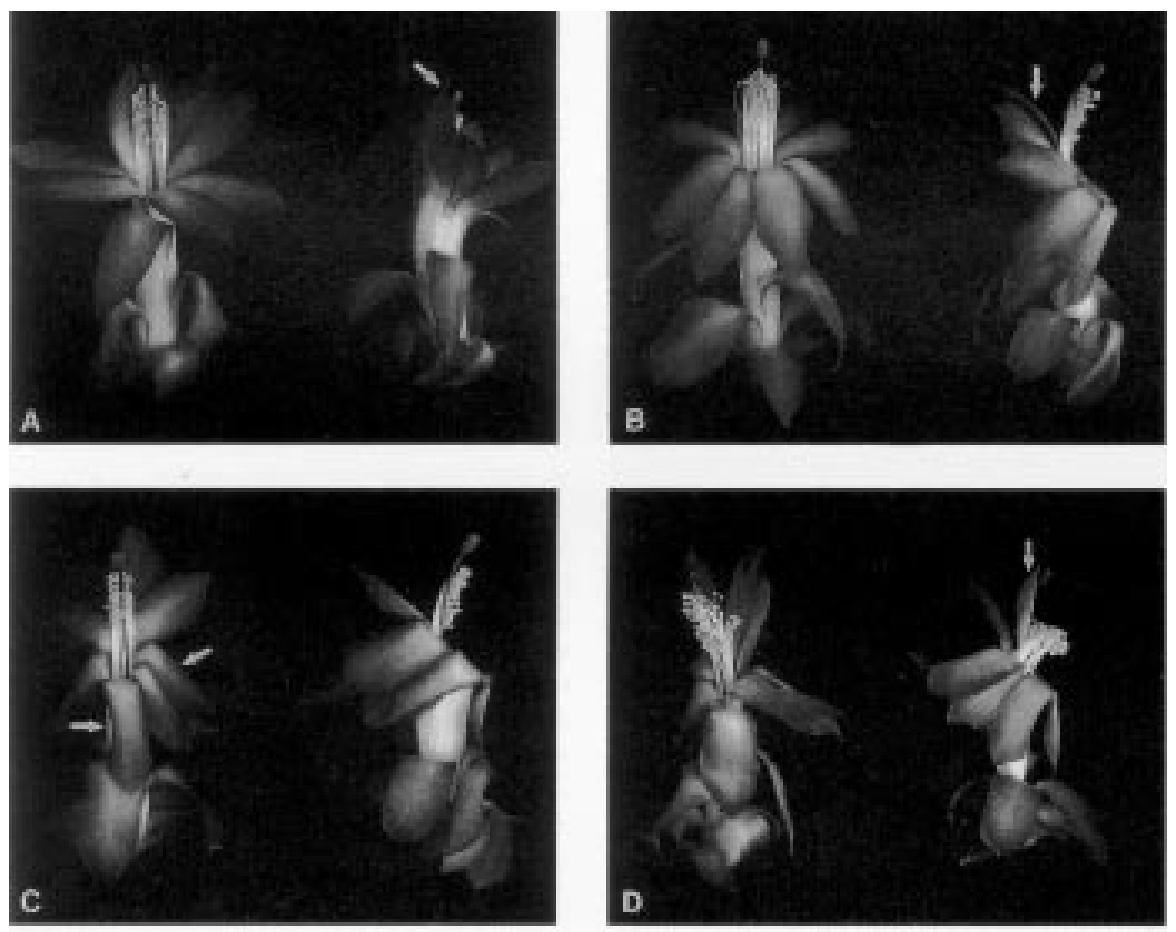

Fig. 2. Floral development stages in Schlumbergera 'Dark Marie' from anthesis to senescence. (A) Early stage, with flower at right showing $\approx 10^{\circ}$ petal orientation for the uppermost apical perianth segment (arrow); (B) middle stage, with flower at right showing an $\approx 45^{\circ}$ petal orientation for the uppermost apical perianth segment (arrow); (C) late stage, with flower showing flaccid petal tips (arrows); (D) senescent stage, with flower at right showing $0^{\circ}$ petal orientation for the uppermost apical perianth segment (arrow). Each photograph shows the (left) ventral and (right) lateral surfaces of intact flowers.
Boyle, T.H. and D. Jacques. 1990. Using photoperiod to control flowering of Holiday cactus. Floral Notes 3(1):4-5.

Deneke, F.C., K.B. Evenson, and R. Craig. 1990. Regulation of petal abscission in Pelargonium xdomesticum. HortScience 25:937-940.

De Jong, J. and F. Garretsen. 1985. Genetic analysis of cut flower longevity in gerbera. Euphytica 34:779-784.

Evensen, K.B. and K.M. Olson. 1992. Forcing temperature affects postproduction quality, dark respiration rate, and ethylene responsiveness of Pelargonium $\times$ domesticum. J. Amer. Soc. Hort. Sci. 117:596-599.

Ganders, F.R. 1976. Self-incompatibility in the Cactaceae. Cactus Succulent J. (Great Britain) 38:39-40.

Grant, V. and W.A. Connell. 1979. The association between Carpophilus beetles and cactus flowers. Plant Syst. Evol. 133:99-102.

Grant, V. and K.A. Grant. 1979. Pollination of Echinocereus fasciculatus and Ferocactus wislizenii. Plant Syst. Evol. 132:85-90.

Harding, J., T. Byrne, and R.L. Nelson. 1981. Heritability of cut-flower vase longevity in gerbera. Euphytica 30:653-657.

Hunt, D.R. 1981. Schlumbergera $\times$ buckleyi.Curtis's Bot. Mag. (New Ser.) 183:119-122.

Kelly, K.L. and D.B. Judd. 1976. Color: Universal language and dictionary of names. Natl. Bur. Standards Special Bul. 440. U.S. Govt. Printing Office, Washington, D.C.

Langton, F.A. 1991. Selection for production traits in flower crops, p. 135-155. In: J. Harding, F. Singh, and J.N.M. Mol (eds.). Genetics and breeding of ornamental species. Kluwer Academic Publ., Dordrecht, The Netherlands.

Liberty Hyde Bailey Hortorium. 1976. Hortus third: A concise dictionary of plants cultivated in the United States and Canada. Macmillan, New York.

Patch, F.W. 1977. It's Christmas every day for Cobia cacti. Florists' Rev. 161(4177):280.

Poole, R.T. 1973. Flowering of Christmas cactus during the summer. HortScience 8:186.

Poole, R.T., R.A. Hamlen, C.A. Conover, R.W. Henley, and A.R. Chase. 1981. Holiday cactus production guide for commercial growers. Ornamental Hort. Commercial Fact Sheet 2. Univ. of Florida, Apopka.

Royal Horticultural Society. 1966. Royal Horticultural Society colour chart. Royal Hort. Soc., London.

SAS Institute. 1985. SAS/STAT guide for personal computers. Version 6. SAS Institute, Cary, N.C.

Taylor, N.P. 1976. More self-incompatibility in cacti. Cactus Succulent J. (Great Britain) 38:67.

Van Eijk, J.P. and W. Eikelboom. 1976. Possibilities of selection for keeping quality in tulip breeding. Euphytica 25:353-359.

Went, F.W. 1982. The physiology of cacti, p. 56-62. In: L. Benson (ed.). The cacti of the United States and Canada. Stanford Univ., Stanford, Calif.

Wu, M.J., W.G. van Doorn, and M.S. Reid. 1991. Variation in the senescence of carnation (Dianthus caryophyllus L.) cultivars. I. Comparison of flower life, respiration and ethylene biosynthesis. Scientia Hort. 48:99-107. 